\author{
Monika Janas, Alicja Zawadzka \\ Faculty of Process and Environmental Engineering, Lodz University of Technology, \\ 90-924 Lodz, Wolczanska 213 \\ monika.janas@edu.p.lodz.pl
}

\title{
ASSESSMENT OF ENVIRONMENTAL IMPACT OF AGRICULTURAL BIOGAS PLANTS
}

\begin{abstract}
Operation of biogas plants, anaerobic fermentation processes, collection and purification of biogas and its subsequent combustion may be a source of environmental hazard. The construction and operation of biogas plants is inextricably connected with the generation and emission of solid, liquid and gaseous pollutants into the environment. The aim of the work is to analyze environmental hazards resulting from the construction and operation of biogas plants. As part of the work, a comprehensive analysis of their impact on individual components of the environment was made. The effect of biogas plants on atmospheric air, soil and water environment and acoustic climate was analyzed and the potential range of these impacts was presented.
\end{abstract}

\section{Key words}

agricultural biogas plant, biomass, biogas, environmental impact

\section{Introduction}

Deepening climate changes and increasing environmental pollution contribute to undertaking actions to reduce emissions from some industrial processes. Power industry is a sector that particularly burdens the environment, especially since it is based mainly on conventional (nonrenewable) resources, i.e. hard coal, crude oil and natural gas. An alternative to burning fossil fuels is the production of energy from renewable sources such as wind, water, sun, geothermal resources and biomass. This last source is the most prospective for Poland. Biomass can be obtained from three main organic wastes: from agri-food industry, from municipal waste and from animal waste (agricultural sector). In Poland, 377,000 tons of waste is produced annually in the fruit and vegetable processing sector and 661,000 tons is generated by meat processing industry. Both types of waste are good raw materials for biogas plants. On the other hand, Polish agriculture produces $80,700,000$ tons of manure and about 35 million $\mathrm{m}^{3}$ of liquid manure per year. Of this about $30 \%$ can be used for biogas production [1]. Depending on the nature and composition of biomass, it can be used for the production of solid fuels, liquid and gas biofuels. A wide range of technologies of biomass processing for energy, biomass availability and diversification are an opportunity for farms that can become important suppliers of energy resources and consumers of energy from these sources [2-4].

One of the processes that use biomass for energy purposes, which can be applied in agricultural farms, is methane, anaerobic fermentation carried out in agricultural biogas plants. According to the type of biomass feedstock, biogas derived from anaerobic fermentation typically contains $52-85 \%$ methane $\left(\mathrm{CH}_{4}\right), 14-50 \%$ carbon dioxide $\left(\mathrm{CO}_{2}\right)$ and trace amounts of hydrogen sulfide $\left(\mathrm{H}_{2} \mathrm{~S}\right)$, ammonia $\left(\mathrm{NH}_{3}\right)$, siloxanes, hydrogen $\left(\mathrm{H}_{2}\right)$, nitrogen $\left(\mathrm{N}_{2}\right)$, oxygen $\left(\mathrm{O}_{2}\right)$ and other gas pollutants. The composition of biogas is variable and depends mainly on the raw material used and technological process being implemented [5].

Biogas production is still very controversial in Poland. On the one hand, biogas plants as new objects in the modern countryside are important for acquiring green energy. On the other hand, the construction and operation of such facilities is connected with the generation and emission of pollutants into the environment [3-5].

The aim of the work is the analysis of threats to the environment and agricultural landscape in the aspect of emerging new installations such as biogas plants. The impact of biogas plants on particular components of the environment including atmospheric air, soil and water as well as acoustic climate was analyzed. 


\section{Characteristics of biogas and agricultural biogas plants}

Directive 2009/28/EC defines biogas as 'gaseous fuel produced from biomass and/or a biodegradable part of waste that can be purified to the quality of natural gas, for use as biofuel, or wood gas' [8]. According to national legislation, biogas is 'the gas obtained from biomass, in particular from installations for treating animal or vegetable waste, sewage treatment plants and landfills', and agricultural biogas is defined as 'the gas obtained in the process of methane anaerobic fermentation of agricultural raw materials, agricultural byproducts, liquid or solid animal manure, by-products, wastes or residues from the processing of products of agricultural origin or forest biomass, or plant biomass collected from the areas other than those recorded as agricultural or forestry, excluding biogas obtained from raw materials originating from sewage treatment plants and landfills' [9]. In its chemical composition, this gas contains mainly methane, which accounts for 52$85 \%$ of the composition of the mixture. Its composition depends strictly on the type of material being fermented and its dry matter content. Typical contents of individual components in biogas are presented in Table 1, while Table 2 gives the amount of biogas yield from various substrates [5-7].

Table 1. Biogas composition

\begin{tabular}{|c|c|c|}
\hline Component & Content \% & Average content \% \\
\hline Methane $\mathrm{CH}_{4}$ & $52-85$ & 65 \\
\hline Carbon dioxide $\mathrm{CO}_{2}$ & $14-48$ & 34.8 \\
\hline Hydrogen sulfide $\mathrm{H}_{2} \mathrm{~S}$ & $0.08-5.5$ & 0.2 \\
\hline Hydrogen $\mathrm{H}_{2}$ & $0-5$ & Trace amounts \\
\hline Carbon monoxide $\mathrm{CO}$ & $0-2.1$ & Trace amounts \\
\hline Nitrogen $\mathrm{N}_{2}$ & $0.6-7.5$ & Trace amounts \\
\hline Oxygen $\mathrm{O}_{2}$ & $0-1$ & Trace amounts \\
\hline Ammonia $\mathrm{NH}_{3}$ & $<1$ & Trace amounts \\
\hline Siloxane & $0-0.02$ & Trace amounts \\
\hline VOC & $<0.6$ & Trace amounts \\
\hline
\end{tabular}

Source: Authors' report based on [3]

Table 2. Amount of biogas and methane acquired from agricultural waste

\begin{tabular}{|c|c|c|c|}
\hline \multirow{2}{*}{ Substrate } & \multicolumn{2}{|c|}{ Amount of biogas } & \multirow{2}{*}{ CH $_{4}$ content [\% vol.] } \\
\cline { 2 - 3 } & {$\left[\mathrm{m}^{3} / \mathrm{t}\right.$ substrate $]$} & {$\left[\mathrm{m}^{3} / \mathrm{t}\right.$ organic dry matter $]$} & \\
\hline Corn silage & $170-200$ & $450-700$ & $50-55$ \\
\hline Cattle slurry & $20-30$ & $200-500$ & 60 \\
\hline Pig slurry & $20-35$ & $300-700$ & $60-70$ \\
\hline Cattle manure & $40-50$ & $210-300$ & 60 \\
\hline Pig manure & $55-65$ & $270-450$ & 60 \\
\hline Chicken manure & $70-90$ & $250-450$ & 60 \\
\hline
\end{tabular}

Source: [5]

The properties of biogas produced in the process of biochemical transformations in the absence of oxygen make it important in the economic sense [3]. Biogas is a medium-energy fuel that can be used in industry, in households and in agriculture as a heat and electric energy carrier, or be used as fuel for vehicles [4-6]. The percentage of methane in biogas determines the calorific value, i.e. energy properties. The greater its share, the greater the calorific value of biogas. Biogas containing about $65 \%$ of methane usually has a calorific value of $23 \mathrm{MJ} / \mathrm{m}^{3}$, which after purification reaches up to $35 \mathrm{MJ} / \mathrm{m}^{3}[6]$.

Agricultural biogas is produced in a set of devices which together constitute a biogas plant. In the biogas plant a strictly defined technological process (methane fermentation of biomass) is carried out and, as a result, biogas is produced. The construction and operation of such an installation is a major resource and logistical challenge. The construction of each such facility is individual and depends on various factors, mainly on the type of batch material. Due to the type of substrates used, biogas plants are classified into several types. One of them are agricultural biogas plants in which agricultural products or wastes from the agri-food industry are processed [2- 
4]. The basic parameters affecting the energy balance of such a biogas plant include the type of material fermented and its dry matter content, quantitative proportions of ingredients (in the case of so-called cofermentation, i.e. fermentation of at least two raw materials from different sources), temperature and its fluctuations over time, hydraulic retention time, amount and frequency of feed supply, fermentation chamber load, frequency and accuracy of mixing $[3,6]$.

An agricultural biogas plant, due to its specificity, is an installation that makes it possible to rationally solve the problem of managing various organic wastes, generating electricity and heat as well as digestates which are an excellent fertilizer, and contributing to the reduction of emissions of harmful substances, mainly methane emissions from the agricultural sector [7].

\section{The object of study}

The analysis of the environmental impact of a biogas plant is based on a functioning agricultural biogas plant. As a result of the combustion of biogas from anaerobic fermentation of organic substrates (maize silages), electricity and heat are generated in the cogeneration unit. The installation consists of a biomass feeding system and a tank of liquid substrates, two digesters operating in a flow-retention system, a storage tank for fermented substrates, a cogeneration unit, an emergency flare, and accompanying infrastructure, which consists of vehicle weighing scales, maneuvering areas and internal roads, transformer station and office facilities. The total area of the agricultural biogas plant is about $1.3 \mathrm{ha}\left(13,000 \mathrm{~m}^{2}\right)$, of which the fermentation block covers an area of about $2000 \mathrm{~m}^{2}$, internal roads, maneuvering areas and other paved areas about 1000 $\mathrm{m}^{2}$, a separation block about $200 \mathrm{~m}^{2}$, a social block about $20 \mathrm{~m}^{2}$, and silage silos about $3600 \mathrm{~m}^{2}$. In the biogas plant, approximately 4,340 MWh of electricity, about 15,662 GJ of thermal energy and about 12,000 ton/year of natural fertilizers are produced per year.

Silage for the production of biogas accumulated in storage silos is fed via a storage tank to digesters where the process of methane (anaerobic) fermentation consisting of four phases takes place. The fermentation liquid transported to a storage tank specifically designed for its collection is then pumped and used as a natural fertilizer in agriculture. The produced biogas is first subjected to a biological desulfurization process. This process is carried out by bacteria called Sulfobacter oxidans, which in the presence of oxygen convert hydrogen sulfide to pure sulfur and water. Only after the removal of hydrogen sulfide, biogas is directed to the cogeneration module - a gas engine in which the chemical energy of biogas is converted into electricity and heat. Part of the electricity is resold to a power plant, while heat energy is used in technological processes (to maintain the necessary temperature in digesters or to dry filter cake). If the cogeneration system does not work, biogas is burnt in a gas flare. Such cases usually last short and are sporadic. The biogas power plant is equipped with devices and subassemblies ensuring safe operation (including biogas detection system, separate level and pressure protection systems) and remote monitoring (control and monitoring automation systems).

\section{Analysis of environmental impact of a biogas plant}

The construction and operation of an agricultural biogas plant, like any other industrial plant, carry some risks. Each such investment causes the generation and emission of solid, liquid and gaseous pollutants to the environment.

\section{Emissions of pollutants to the atmosphere}

The greatest concerns are related to the emissions of atmospheric pollutants such as nitrogen dioxide, sulfur dioxide, carbon monoxide, particulate matter, aromatic hydrocarbons and non-standard odorous substances (hydrogen sulfide). During the operation of a biogas plant, the source of small stack emission to the atmosphere is biogas combustion in the TCG 2016 V16 gas engine coupled with an electric generator (CHP), or in emergency situations in a flare, i.e. an emergency flare to burn excess biogas.

Emissions of nitrogen dioxide, carbon monoxide and formaldehyde were calculated based on engine emission standards defined by the manufacturer, and sulfur dioxide emissions were calculated using values presented in the study entitled "Guidelines for provincial emission inventories for current assessments and air protection programs" [10]. The results of emissions from energy biogas combustion in a cogeneration unit are summarized in Table 3. This emission does not exceed the emission standards for biomass combustion installations [11]. 
Table 3. Calculated emission of pollutants from the CHP unit

\begin{tabular}{|l|c|c|}
\hline \multirow{2}{*}{ Pollutant type } & Emission & $\begin{array}{c}\text { Emission standard for biomass } \\
\text { combustion installations }\end{array}$ \\
\cline { 2 - 3 }$\left[\begin{array}{c}\text { [mg/m } \\
\text { S }]\end{array}\right.$ \\
\hline Sulfur dioxide $\mathrm{SO}_{2}$ & 8 & 200 \\
\hline Nitrogen dioxide $\mathrm{NO}_{2}$ & 350 & 500 \\
\hline Carbon monoxide $\mathrm{CO}$ & 210 & 300 \\
\hline Formaldehyde $\mathrm{CH}_{2} \mathrm{O}$ & 45 & 60 \\
\hline
\end{tabular}

Source: Authors'

During the operation of an agricultural biogas plant, the source of fugitive emissions is the process of maize ensiling and storage in silos as well as storage and application of fermentation liquid in the fields. Maize silage is produced and stored in two silos. In order to ensure anaerobic conditions, the silos are filled in the shortest possible time, and then they are tightly covered with plastic sheets and loaded to keep the sheeting in place. The range of emissions of compounds being the products of lactic fermentation (lactic acid, acetic acid, ethyl alcohol, carbon dioxide, hydrogen and others) is limited to the nearest vicinity of the silos. The fermentation liquid is stored in sealed tanks, which practically minimizes emissions to the air. The retention time in digesters enables complete degradation of the organic part of the substrate and elimination of odor substances such as volatile fatty acids and hydrogen sulfide due to biochemical transformation. As a result, the fermentation liquid contains only traces of volatile organic acids causing the emission of odors such as: acetic acid, butyric acid, lactic acid or propionic acid. These emissions occur cyclically, without causing a nuisance in the areas adjacent to the plant.

In the biogas plant there is minimal fugitive emission (including carbon monoxide, oxide and nitrogen dioxide, aldehydes, lead and polyaromatics (benzo[a]pyrene)), which is associated with the combustion of fuels in diesel engines (bulldozers) and means of transport moving around it. It has a negligible effect on the cleanliness of air in the biogas plant area.

\section{Impact on the soil and water environment}

The main waste produced in the analyzed agricultural biogas plant as a result of anaerobic fermentation of substrates of organic origin (maize silage) is fermentation liquid. The amount of fermentation liquid produced in a biogas plant per year is shown in Table 4.

Table 4. Amount of produced fermentation liquid vs. the quantity of loaded substrates

\begin{tabular}{|l|c|c|c|c|c|c|}
\hline \multirow{3}{*}{ Substrates } & Mass & $\begin{array}{c}\text { Organic dry } \\
\text { matter }\end{array}$ & $\begin{array}{c}\text { Organic dry } \\
\text { matter prior } \\
\text { to the } \\
\text { process }\end{array}$ & $\begin{array}{c}\text { Organic dry } \\
\text { matter } \\
\text { decomposi- } \\
\text { tion }\end{array}$ & $\begin{array}{c}\text { Organic dry } \\
\text { matter after } \\
\text { the process }\end{array}$ & Mass \\
\cline { 2 - 7 } & {$[$ ton/year] } & {$[\%]$} & {$[$ ton/year] } & {$[\%]$} & [ton/year] & {$[$ ton/year] } \\
\hline Maize silage & 10000 & 96 & 3360 & 60 & 1344 & 7984 \\
\hline Water & 4000 & 0 & 0 & 0 & 0 & 40000 \\
\hline Total: & $\mathbf{1 4 0 0 0}$ & & $\mathbf{3 3 6 0}$ & & & $\mathbf{1 1 9 8 4}$ \\
\hline
\end{tabular}

Source: Authors'

The 14,000 ton/year of substrates processed in the biogas plant per year results in the decomposition of 2016 ton/year of dry organic matter and production of about 12,000 ton/year of fermentation liquid (about $7.2 \%$ d.m.) per year. The fermentation mixture is recovered by means of the R10 recovery process - Spreading on the ground for fertilization or soil improvement - under the conditions specified, i.e. in the Regulation on the R10 recovery process of the Minister of the Environment of 20 January 2015 [12].

The biogas plant also produces small amounts of waste from technical and social facilities, waste from maintenance and repairs of used machines, packaging waste as well as cleaning waste. Due to the proper management of solid waste - selective collection and temporary collection of waste, and then transfer for 
recovery or disposal to appropriate companies with proper permits for waste management required by law, they do not pose a threat to the environment.

In the analyzed agricultural biogas plant no process wastewater is generated. In the process consisting in the production of biogas, due to cooling of the biogas in a shell-and-tube exchanger only a condensate of water is formed with traces of impurities dissolved in it, i.e. ammonia and hydrogen sulfide. The resulting condensate is collected in a check tank and then recycled to the biogas plant. Therefore, only wastewater from social facilities is generated in the plant. It is discharged into tight septic tanks which, in turn, are successively emptied with the use of specialized vacuum trucks transporting wastewater to a sewage treatment plant.

In addition, as a result of rinsing internal roads and maneuvering area in the biogas plant on the surface of paved areas rainwater is contaminated due to settling of air (particulate matter) and vehicle pollutants. Concentrations of oil derivatives and total suspended solids on the plant site are definitely lower than the maximum permissible concentration values of these substances in sewage introduced into water and soil established in the Regulation of the Minister of Environment of 18 November 2014 on conditions to be met when introducing sewage into water or soil, and on substances particularly harmful to the aquatic environment, i.e. $<100 \mathrm{mg} / \mathrm{l}$ of total suspended solids and $<15 \mathrm{mg} / \mathrm{l}$ of petroleum hydrocarbons [13]. Rainwater is also formed within the silage silos. Leachates from the silos are discharged into the nearby wells and then used in the anaerobic fermentation process. In order to reduce formation of the leachates the silos are tightly covered with plastic sheets.

\section{Impact on the acoustic climate}

In the biogas plant, noise is generated by a functioning cogeneration unit and pumping system as well as vehicle traffic on the plant site. Due to the location of devices inside the building and low traffic, the permissible noise levels are not exceeded in the nearest areas in terms of acoustic climate, both at day and night time, as defined in the Regulation of the Minister of Environment [14].

\section{Summary and conclusions}

The construction and operation of every industrial plant, including an agricultural biogas plant, poses a threat to the natural environment. To indicate the impact of biogas plants on the environment, a comparison was made in the form of the Leopold matrix which in three steps evaluates the impact of the analyzed agricultural biogas plant on individual elements of the environment - Table 5.

In the matrix, a potential environmental impact was assessed. Digits specify the subjective impact of biogas plants on the environment (small -1 to 2 , moderate -3 to 5 and large -6 to 10 ). 
Table 5. Leopold matrix for potential environmental impacts of biogas plants

\begin{tabular}{|c|c|c|c|c|c|c|c|}
\hline $\begin{array}{l}\text { Environmental } \\
\text { of the environment }\end{array}$ & 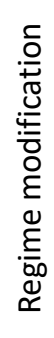 & 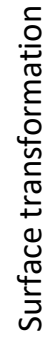 & 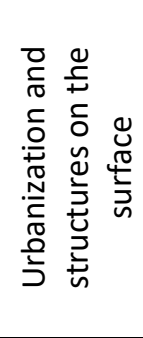 & 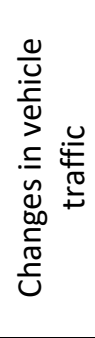 & 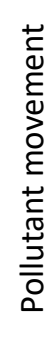 & 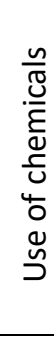 & 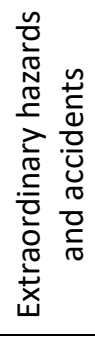 \\
\hline Soil & & & & & & & \\
\hline Water & & & & & & & \\
\hline Atmosphere & & & & & & & \\
\hline Land use & & & & & & & \\
\hline $\begin{array}{l}\text { Qualities of the } \\
\text { landscape }\end{array}$ & & & & & & & \\
\hline Infrastructure & & & & & & & \\
\hline
\end{tabular}

Source: Authors'

The most important impacts of agricultural biogas plants on the natural environment, which according to Leopold's matrix have medium intensity, include atmospheric air - covering energy emissions of gases generated as a result of biogas combustion in CHP units and noise propagation, and water and soil environment - in terms of potential soil and groundwater contamination with fermentation liquid, leachates from maize silage silos and rainwater. However, due to the full tightness of all installations, the use of protective devices and correct and environmentally safe methods of handling substrates, fermentation mixture, fermentation liquid, generated sewage and solid waste, the analyzed agricultural biogas plant does not have a significant negative impact on the environment, and the occurring impacts are small and do not go beyond the plant boundaries.

The biogas production technology has a high development potential in Poland due to significant resources of raw materials, the demand for energy in a distributed system and the need to meet obligations concerning production of energy from renewable sources [2]. It also provides opportunities for rural development, new jobs, stable market for agricultural products and economic development. The undeniable advantages include, among others, creation of a local source of 'clean' electricity and heat, and reduction of pollutant emissions through the use of renewable fuel for the production of energy (substitution of fossil fuels), and thus the implementation of low-carbon economy programs. Combustion of biogas is associated with a hundredfold lower emission of sulfur dioxide and three times lower emissions of nitrogen oxides as compared to emissions from coal combustion. In addition, the stable and efficient organic fertilizer produced in biogas plants in the form of fermentation liquid ensures recycling of nutrients in the soil and reduces the demand for fertilizers [3-6].

Many economic, social and environmental benefits that result from biogas production mean that biogas plants have a chance for dynamic development in Poland. 


\section{Acknowledgements}

This research did not receive any specific grant from funding agencies in the public, commercial, or not-forprofit sectors.

\section{References}

[1] Environmental Protection 2016, Central Statistical Office, Warsaw

[2] M. Collotta, G. Tomasoni, The environmental sustainability of biogas production with small sized plant, Energy Procedia. 128 (2017) 38-45.

[3] B. Igliński, R. Buczkowski, M. Cichosz, Biogas production in Poland - current state, potential and perspectives. Renew Sust Energ Rev. 50 (2015) 686-695.

[4] A. Oniszk-Popławska, M. Matyka, E.D. Ryńska, Evaluation of a long-term potential for the development of agricultural biogas plants: A case study for the Lubelskie Province, Poland. Renew Sust Energ Rev. 36 (2014) 329-349.

[5] M. Fugol, J. Szlachta, Zasadność kiszonki z kukurydzy i gnojowicy świńskiej do produkcji biogazu. Inżynieria Rol. 1 (2010) 169-174.

[6] M. Muradin, Z. Foltynowicz, Potential for producing biogas from agricultural waste in rural plants in Poland. Sustainability. 6(8) (2014) 5065-5074.

[7] M. Kimming, C. Sundberg, A. Nordberg, A. Baky, S. Bernesson, et al., Biomass from agriculture in small-scale combined heat and power plants - A comparative life cycle assessment, Biomass and Bioenergy. 35 (2011) $1572-1581$.

[8] European Parliament Directive 2009/28/EC of the European Parliament and of the Council of 23 April 2009 Off J Eur Union, 140 (2009).

[9] Ustawa z dnia 20 lutego 2015r. o odnawialnych źródłach energii (Dz.U. 2015 poz. 478).

[10] Wskazówki dla wojewódzkich inwentaryzacji emisji na potrzeby ocen bieżących i programów ochrony powietrza, Ministerstwo Środowiska, Główny Inspektorat Ochrony Środowiska, Warszawa 2003.

[11] Rozporządzenie Ministra Środowiska z dnia 4 listopada 2014 r. w sprawie standardów emisyjnych dla niektórych rodzajów instalacji, źródeł spalania paliw oraz urządzeń spalania lub współspalania odpadów (Dz.U. 2014 poz. 1546).

[12] Rozporządzenie Ministra Środowiska z dnia 20 stycznia 2015 r. w sprawie procesu odzysku R10 (Dz.U. 2015 poz. 132).

[13] Rozporządzenie Ministra Środowiska z dnia 18 listopada 2014 r. w sprawie warunków, jakie należy spełnić przy wprowadzaniu ścieków do wód lub do ziemi, oraz w sprawie substancji szczególnie szkodliwych dla środowiska wodnego (Dz.U. 2014 poz.1800).

[14] Rozporządzenie Ministra Środowiska z dnia 1 października 2012 r. zmieniające rozporządzenie w sprawie dopuszczalnych poziomów hałasu (Dz.U. 2012 poz.1109). 